\title{
Effects of College Life Satisfaction, Major Satisfaction and Academic Self-efficacy on School Loyalty
}

\author{
Jae-Hyuk Yang ${ }^{1}$ and Jong-Taek Seo $^{2 *}$ \\ ${ }^{1}$ Daejin University, Korea \\ 2*Konkuk University, Korea \\ 1joinco@hanmail.net, ${ }^{2 *}$ suho1793@hanmail.net
}

\begin{abstract}
The purpose of this study is to establish an intimate relationship between the school and college students to enable continuous learning without dropping out. The following terminologies as used in this study were defined as follows. First, 'school life satisfaction' indicates the overall level of student's satisfaction with school life. Second, the degree of 'major satisfaction' with your choice. Third, 'academic self-efficacy' refers to the ability to perform academic studies. Finally, 'school loyalty', indicates the formation of a friendly relationship with the affiliated university. Through this, the effects of school life satisfaction, major satisfaction, and academic self-efficacy on school loyalty were analyzed. As a result of the study, it was found that school life satisfaction and major satisfaction had a significant effect on school loyalty, but academic self-efficacy did not. Through this study, it will be possible to establish important factors that affect the relationship between the school and its students and contribute to improving the educational services that schools must offer students, and present directions for continuous research on the improvement of education based on the student's perception. In future research, it is necessary to proceed with the study by adding various factors to prevent students from dropping out.
\end{abstract}

Keywords: University life satisfaction, Major satisfaction, Academic self-efficacy, School loyalty

\section{Introduction}

University students recognize college as an institution of higher education that seeks truth, and as the last step before transitioning to the professional world; thus, it is an important period to develop the competencies required by the respective occupational group [1]. In addition, it is expected that through university education, the students will acquire in-depth knowledge on their majors and return to society with expertise [2]. However, recently, college students have been dropping out of school for various reasons. A closer look at the statistics shows that the number is on a steady increase from $3.6 \%$ in 2010 to 5.2\% in 2018 and $7.0 \%$ in 2020 [3]. This phenomenon can result in a decrease in the school-age population and a decrease in the enrollment rate of students, which will eventually pose a threat to the existence of the university.

As the domestic school-age population continued to decline from 2000, the school-age considered for university admission (18-years-old), decreased from 8,268,889 in 2000 to $6,97,847$ in 2010 , by 130,000 in 10 years. It is predicted that it will further decrease to

Article history:

Received (March 21, 2021), Review Result (April 19, 2021), Accepted (June 15, 2021) 
$500,000,126$ in 2020, 440,837 in 2030, and 43,2391 in 2040 [4]. Therefore, universities should pay great attention not only to the continuous recruitment of students, but also minimize the dropout rate of college students, who are a secured resource for the future. We are not only interested in selecting students, but also in maintaining and managing students professionally. In the future, universities that minimize dropout rates will be able to operate smoothly, while those that fail to solve the dropout problem will have financial difficulties [5].

Therefore, university authorities have developed an image and actual conditions that students think, feel, and evaluate, as well as the academic system of each university, so that students can apply to a particular university and complete their studies there with the aid of various university policies and educational support plans. It is pouring out various policies and support measures considered. Therefore, there is a need for practical research on the evaluation and satisfaction of students (undergraduate) for each college or major engineering department; in addition to the school loyalty which affects the school's conditions and willingness of students to continue with academics.

This study shows that the degree of satisfaction with college life [2], which is the feeling, emotion, or attitude that students get while living in a particular school, significantly influence their desires in various activities, personal characteristics, and choice of majors within their chosen major [6]. Through interaction with the conditions surrounding the subject, knowledge, and performance are improved in an academic context; in addition, there are improvements in the emotional, cognitive, and affective aspects (i.e., positive thoughts and attitudes) about their major. It was analyzed how academic self-efficacy, the mediating driving force, affects school loyalty [7], which is defined as a friendly attitude toward school and a willingness to maintain a friendly relationship.

To this end, the research problems were selected based on the review of previous studies, and an attempt was made to analyze the structural relationship between variables. The research questions calculated for analysis are as follows.

Research Question 1. How does satisfaction with college life affect school loyalty?

Research Question 2. How does major satisfaction affect school loyalty?

Research Question 3. How does academic self-efficacy affect school loyalty?

\section{Theoretical background}

\subsection{Satisfaction with college life}

University life satisfaction is a very important aspect of successful university life, and it has an important influence in terms of personal growth and development depending on how well one adapts to school life. This is because schools play a vital role in the student's harmonious adaptation to changes in the social environment through the process of constant change and growth; thus, school is not just a place to acquire knowledge but helps in fostering a sense of cooperation, consideration, desirable values, and achievements. In addition, college students need to spend their college life satisfactorily, and students are satisfied in school adapt well to life outside the school, and have a higher sense of accomplishment and confidence [8]. In other words, college life satisfaction is the degree to which students are satisfied with their educational activities in terms of human relationships with professors and peers in a school environment. It is a subjective feeling and consists of an attitude of happiness and satisfaction in school life. It can be defined as a subjective and personal phenomenon according to the individual's perspective based on the agreement between reality and one's expectations [9]. 


\subsection{Major satisfaction}

Major satisfaction has a strong influence on aptitude and refers to the degree to which one's current major is satisfied compared to the criteria for career and occupation set by an individual [10][11]. If college students match the criteria for their preferred career and major in it, it can be expected that their major satisfaction will also be high [12].

Shin \& Johnson (1978) defined major satisfaction as "a product of the judgment process that evaluates the department to which one belongs in comparison with the criteria for career or occupation set by an individual" [13]. In other words, satisfaction with a major can be evaluated by comparing one's expectations with the vocational reference group, and individual expectations, careers, and judgment on the vocational reference group are influenced by social. It can be seen that perception affects major satisfaction.

\subsection{Academic self-efficacy}

Academic self-efficacy refers to the judgment of the learner's ability to manipulate and act accordingly to perform academic tasks. Looking at the various definitions of academic selfefficacy, Bong (1997) stated that students can perceive themselves as to whether they can successfully perform a given academic task to a certain level [14]. Kim and Park (2001) defined academic self-efficacy as the ability for learners to acquire knowledge, learn, and perform in specific situations [15]. Therefore, academic self-efficacy refers to a personal judgment made by a learner about the ability required to acquire new knowledge or skills [16]. The learner makes judgments about the ability to organize and execute the actions necessary to perform academic tasks according to their level of self-confidence, and this confidence is achieved through the cognitive judgment of their ability [17][18].

\subsection{School loyalty}

The most relevant part of college students' school loyalty is the degree of adaptation to the school and major and the reason for choosing it. When students join their university of choice, they naturally identify with the school, and their interest in the school and their majors increase. Therefore, the academic life at the university is also faithful, and this has a positive effect on the school grades. This reduces the tendency of students to take a leave of absence or move to another university. Of particular importance is the degree to which the department is consistent with one's aptitude and interests, which affects school loyalty throughout university life. There will be a difference in the overall school lifestyle between students who simply choose a major based on their SAT scores when entering college, and students who choose a major that is related to their aptitude and interest, and there will be a clear difference in school loyalty in regards to negative and positive attitudes [19].

\section{Research subjects and research methods}

The subject of this study were 279 students of A University located in Gyeonggi-do. By grade, there were 78 first graders, 100-second graders, 66 third graders, and 35 fourth graders. By gender, 95 male students and 184 female students. In the classification by major, 113 students took up humanities, 103 students selected engineering, 55 students selected arts, and 8 others. An analysis was conducted for one week using a questionnaire, and descriptive statistical analysis, correlation analysis, and multiple regression analysis were conducted using the IBM SPSS (Statistical Package for the Social Science) 21 program.

The demographic data of the study subjects are shown in [Table 1]. 
Table 1. Demographic data of study subjects

\begin{tabular}{|c|c|c|c|}
\hline & Division & Number of respondents (person) & Percentage (\%) \\
\hline \multirow{3}{*}{ Gender } & Male & 95 & 34.1 \\
\cline { 2 - 4 } & Female & 184 & 65.9 \\
\hline \multirow{3}{*}{ By grade } & 1 & 78 & 28.0 \\
\cline { 2 - 4 } & 2 & 100 & 35.8 \\
\cline { 2 - 4 } & 3 & 66 & 23.7 \\
\cline { 2 - 4 } & 4 & 35 & 12.5 \\
\hline \multirow{3}{*}{ By major } & Humanities & 113 & 40.5 \\
\cline { 2 - 4 } & Engineering & 103 & 36.9 \\
\cline { 2 - 4 } & Art & 55 & 19.7 \\
\cline { 2 - 4 } & Etc. & 8 & 2.9 \\
\hline
\end{tabular}

\section{Results}

\subsection{Descriptive statistics}

To demonstrate the general trend for each variable, the mean, standard deviation, minimum value, maximum value, skewness, and kurtosis were calculated and presented as in [Table 2]. The average of each variable was college life enjoyment $\mathrm{M}=3.553$ ( $\mathrm{SD}=.705$ ), major satisfaction $\mathrm{M}=3.632$ ( $\mathrm{SD}=.831$ ), academic self-efficacy $\mathrm{M}=3.369(\mathrm{SD}=.907)$, school loyalty $\mathrm{M}=1.950$ ( $\mathrm{SD}=.920)$. It was confirmed that the standard skewness for all measurement variables was \pm 2 or less, and the standard kurtosis was \pm 7 or less, forming a normal distribution.

Table 2. Descriptive statistics

\begin{tabular}{|c|c|c|c|c|c|c|}
\hline Variable & $\begin{array}{c}\text { Average } \\
(\mathrm{M})\end{array}$ & $\begin{array}{c}\text { Standard } \\
\text { Deviation (SD) }\end{array}$ & $\begin{array}{c}\text { Minimum } \\
\text { value }\end{array}$ & $\begin{array}{c}\text { Maximum } \\
\text { value }\end{array}$ & Skewness & Kurtosis \\
\hline Satisfaction with college life & 3.553 & .705 & 1.00 & 5.00 & -.071 & -.039 \\
\hline Major satisfaction & 3.632 & .831 & 1.00 & 5.00 & -.653 & .819 \\
\hline Academic self-efficacy & 3.369 & .907 & 1.00 & 5.00 & -.240 & -.384 \\
\hline School loyalty & 1.950 & .920 & 1.00 & 5.00 & .825 & .441 \\
\hline
\end{tabular}

*School loyalty is reverse coding

\subsection{Correlation analysis}

In this study, the correlation between each variable was analyzed and the results presented as in [Table 3]. School loyalty showed a positive $(+)$ correlation in college life enjoyment and major satisfaction, but there was no correlation with academic self-efficacy.

Table 3. Correlation analysis

\begin{tabular}{|c|c|c|c|c|}
\hline Variable & 1 & 2 & 3 & 4 \\
\hline Satisfaction with college life & 1 & & & \\
\hline Major satisfaction & $.467 * *$ & 1 & & \\
\hline Academic self-efficacy & $.232 * *$ & $.334 * *$ & 1 & 1 \\
\hline School loyalty & $-.172 * *$ & $158^{* *}$ & -.003 & \\
${ }_{* *}^{*} p<.01$ & & &
\end{tabular}




\subsection{Multiple regression analysis}

Before the multiple regression analysis, it was confirmed that all variables showed values of tolerance of 0.1 or more and Variance Inflation Factor (VIF) of 2.0 or less; thus, no multicollinearity occurred. The results of multiple regression analysis are shown as in [Table 4]. The explanatory power of the model consisting of college life satisfaction, major satisfaction, and academic self-efficacy was $37.3 \%\left(\operatorname{adj} . \mathrm{R}^{2}=36.6\right)$, and the F value was 53.303, which was statistically significant at the significance level of .05 . Among the independent variables, it was found that college life satisfaction $(\beta=.439, \mathrm{p}<.05)$ and major satisfaction $(\beta$ $=.292, \mathrm{p}<.05)$ statically predicted school loyalty. In terms of academic self-efficacy, the significance level was .059 and was excluded from the model.

Table 4. Multiple regression analysis results

\begin{tabular}{|c|c|c|c|c|c|c|c|c|}
\hline \multirow{2}{*}{$\begin{array}{c}\text { Subordination } \\
\text { variable }\end{array}$} & \multirow{2}{*}{$\begin{array}{c}\text { Independent } \\
\text { variable }\end{array}$} & \multicolumn{2}{|c|}{$\begin{array}{c}\text { Non- } \\
\text { standarddization } \\
\text { factor }\end{array}$} & \multirow{2}{*}{$\begin{array}{c}\begin{array}{c}\text { Standardization } \\
\text { factor }\end{array} \\
\text { B }\end{array}$} & \multirow[t]{2}{*}{$\mathrm{T}$} & \multirow[t]{2}{*}{$\mathrm{P}$} & \multicolumn{2}{|c|}{$\begin{array}{c}\text { Collinearity } \\
\text { Statistics }\end{array}$} \\
\hline & & B & $\begin{array}{c}\text { Standard } \\
\text { error }\end{array}$ & & & & Tolerance & VIF \\
\hline \multirow{4}{*}{$\begin{array}{l}\text { School } \\
\text { loyalty }\end{array}$} & (a constant) & $\begin{array}{c}1.61 \\
2 \mathrm{E}- \\
16 \\
\end{array}$ & .045 & & .000 & 1.000 & & \\
\hline & $\begin{array}{c}\text { Satisfaction } \\
\text { with college } \\
\text { life }\end{array}$ & .439 & .051 & .439 & 8.538 & .000 & .882 & 1.134 \\
\hline & $\begin{array}{c}\text { Major } \\
\text { satisfaction }\end{array}$ & .291 & .050 & .292 & 5.804 & .000 & .923 & 1.084 \\
\hline & $\begin{array}{c}\text { Academic } \\
\text { self-efficacy }\end{array}$ & .095 & .050 & .094 & 1.895 & .059 & .952 & 1.051 \\
\hline \multicolumn{9}{|c|}{$\mathrm{R}^{2}\left(\operatorname{adj} . \mathrm{R}^{2}\right)=.373(.366) \mathrm{F}=53.303, \mathrm{p}=.000$} \\
\hline
\end{tabular}

\subsection{Factor analysis}

A total of 300 questionnaires were distributed, and a total of 279 questionnaires were used for the analysis, excluding questionnaires with poor responses. The characteristics of the questionnaire used in this study are shown in [Table 5].

Table 5. Configuration of measurement tools

\begin{tabular}{|c|c|c|c|c|}
\hline Domain & $\begin{array}{c}\text { Researcher of the } \\
\text { referenced tool }\end{array}$ & Contents of the question & $\begin{array}{c}\text { Number } \\
\text { of items }\end{array}$ & $\begin{array}{c}\text { Cronbach's } \\
\text { alpha }\end{array}$ \\
\hline $\begin{array}{c}\text { Satisfaction } \\
\text { with college life }\end{array}$ & {$[2]$} & $\begin{array}{c}\text { A state in which individuals feel } \\
\text { comfortable with psychological stability } \\
\text { and enjoyment in exchanges [through } \\
\text { interactions?] with members of school life. }\end{array}$ & 4 & .810 \\
\hline $\begin{array}{c}\text { Major } \\
\text { satisfaction }\end{array}$ & {$[20]$} & $\begin{array}{c}\text { In regards to school life, level of } \\
\text { satisfaction with major selection, major } \\
\text { study, major class, major professor. }\end{array}$ & 4 & .854 \\
\hline $\begin{array}{c}\text { Academic self- } \\
\text { efficacy }\end{array}$ & {$[21]$} & $\begin{array}{c}\text { Confidence in using knowledge, abilities, } \\
\text { attitudes and thinking skills, information } \\
\text { literacy skills, and computer programs } \\
\text { necessary for basic learning in school. }\end{array}$ & 4 & .877 \\
\hline School loyalty & {$[23]$} & $\begin{array}{c}\text { Assessment of factors that negatively } \\
\text { affect the student's perception of a } \\
\text { particular school and academic continuity. }\end{array}$ & 4 & .844 \\
\hline
\end{tabular}




\section{Conclusion}

In this study, a study was conducted to prevent drop out from school through successful adaptation to school life and increased satisfaction with the affiliated university through the improvement of various social and learning experiences by college students. The results are summarized as follows.

First, it was found that college life satisfaction had a significant effect on school loyalty. The degree of satisfaction with college life is an evaluation of the current school life in the college that one is affiliated to compared to the expectations of college life as set by an individual; thus, it can be seen that the satisfaction level has a profound effect on one's future career path. Low satisfaction with overall college life leads to a decline in grades due to loss of interest in learning, and problems such as alienation from school, school maladjustment, dropout, and deprivation of potential opportunities for individuals occur. This phenomenon will appear as a result of lowering loyalty to the school, which eventually results in the student leaving the school. Therefore, universities should strive to provide a variety of services, such as developing various teaching and learning methods and improving academic administration services, to increase students' satisfaction with college life, open various communication channels with school members, and improve organic relationships with students.

Second, it was found that major satisfaction had a significant effect on school loyalty. The degree of satisfaction of a college student's major is an important factor that determines not only college life, but also the future career direction and ultimate career for the major depending on the choice of the individual [27]. In other words, it is a complex concept that leads to defining factors, such as intimacy or psychological attachment to the department offering the major. The

higher the degree of satisfaction with the major, the better the adaptability to school life, and it can be predicted that it will have a positive effect on one's career after graduation [28]. In addition, after graduation, alumni recommend their alma mater to prospective students or participate in alumni associations, and will show a positive attitude in maintaining a friendly relationship with the school continuously through donations, etc. This attitude naturally shows as a result of increased interest and loyalty to the school.

Third, it was found that academic self-efficacy did not significantly affect school loyalty. Academic self-efficacy, an important factor that influences academic achievement, is a judgment on one's ability to organize and implement actions necessary for the performance of academic tasks. Because they are strong, they are less affected by satisfaction with the instructor or knowledge of their major, and they learn to acquire more by themselves [16][29]. Therefore, the higher the academic self-efficacy, the more likely the students are to choose a rogue [tougher?] assignment or subject in the academic context and to seek another university or major to challenge more possibilities of success. On the contrary, students with low academic self-efficacy will lose their interest in school life and related majors, resulting in lowered motivation, which in turn leads to a high probability of dropping out; thus, their loyalty to the school will naturally decline.

Through the above results, the significance of this study is summarized as follows. The period as a college student involves a preparatory process for producing an empowered member of society, and it is not only a period to pursue academic knowledge, but also improve selfdevelopment and quality of life. In this study, students' satisfaction with college life, major satisfaction, and academic self-efficacy are selected as important factors affecting the relationship between school and the students currently in colleges. The relationship with school loyalty was analyzed. In future studies, various factors are added to prevent college students 
from dropping out of the way and continuous research is needed to achieve a successful school life.

\section{References}

[1] S. T. Moon, M. H. Park, and M. B. Yang, "The relationships among human relationship, the personal initiative in learning and vocational adaptability on university students," The Korean Society for the Study of Career Education, vol.25, no.3, (2012)

[2] Y. S Jang, "Discriminant and predictive analyses of university students' career decisions according to career adaptability, social support, university life satisfaction, major relevance, academic self-efficacy, occupational engagement," The Graduate School of KonKuk University, Seoul Korea, (2019)

[3] Journal of Educational Evaluation, https://www.academyinfo.go.kr/search/search.do [accessed on March. 8. 2021]

[4] Maeil Business Newspaper, https://www.mk.co.kr/news/society/view/2018/06/384292/ [accessed on May. 02. 2019]

[5] S. Y. Kim, "A study on exploring the academic persistence and dropout of Korean universities and colleges' students," The Journal of Korean Education, vol.33, no.4, pp.33-62, (2006)

[6] Y. J. Han. "The study on the relationship between the degree of instruction participation and major satisfaction and the employment preparation behavior by the major selection motive and their work valuers of university students-Targeted on the university students who specialized in cooking/dining related," The Graduate School of Kyungsung University, Gyeongsangnam-do Korea, (2014)

[7] E. K. Chung and M. D. Oh, "The effect of NCS based education service quality on student's loyalty to college and self-confidence in getting a job," The Korea Contents Society, vol.19, no.8, (2019)

[8] R. M., Ryan and E. L. Deci, "The darker and brighter sides of human existence: Basic psychological needs as a unifying concept," Psychological Inquiry, vol,11, no,4, (2000)

[9] C. K. Lee, "An effects of enjoyment factor of sports club activity in university on sports commitment and university life satisfaction," The Graduate School of Education Kyung Hee University, Seoul Korea, (2014)

[10] Y. M. Park and J. I. Yang, "The effects of job stress on satisfaction with the department: Verification of mediating effect of self-efficacy and career barrier," Korean Employment and Career Association, vol.9, no.2. pp.55-77, (2019)

[11] Y. H. Jung and J. H. Yang, "The effect of major satisfaction and career decision-making self-efficacy on employment stress of the pre-service teachers who majored early childhood education," Association for Future Early Childhood Education, vol.20, no.3, pp.229-248, (2013)

[12] H. I. Park and J. K. Koo, "Consensual qualitative research of career issues by undergraduate students with low major satisfaction that experience discordance of major-aptitude," The Korean Society for the Study of Career Education, vol.24, no.4, pp.173-190, (2011)

[13] D. C. Shin and D. M. Johnson, "Avoid happiness as an overall assessment of the quality of life," Social Indicators Research, vol.5, pp.475-492, (1978)

[14] M. Bong, "Generality of academic self-efficacy judgments: Evidence of hierarchical relations," Journal of Educational Psychology, vol.89, pp.696-709, (1997)

[15] A. Y. Kim and I. Y. Park, "Construction and validation of academic self-efficacy scale," The Journal of Education Research, vol.39, no.1, pp.95-123, (2001)

[16] A. Bandura, "Social foundations of thought and action: A social cognitive theory," Englewood Cliffs, NJ: Prentice Hall, (1986)

[17] S. J. Lee, K. H. Kim, and Y. R. Kim, "Moderating effect of self-determination motivation between academic self-efficacy and self-regulated learning strategies of middle school students," Korean Education Inquiry, vol.35, no.4, pp.65-94, (2017) 
[18] A. Bandura, "Perceived self-efficacy in cognitive development and functioning," Educational Psychologist, vol.28, no.2, pp.117-148, (1993)

[19] M. J. Park, "The influence of major-interest correspondence on course maturity and satisfaction with major," The Graduate School of KyungHee University, Seoul Korea, (2008)

[20] M. J. Oh, "The effect of college student's career identity and meaning in life on adjustment to college," The Graduate School of Sookmyung Women's University, Seoul Korea, (2014)

[21] M. S. Kang, “The influence of undergraduate students' self-directedness and major satisfaction upon career exploration behavior and the mediating effect of employability," Department of Child and Adolescent Welfare the Graduate School of Hanseo University, Chungcheongnam-do Korea, (2015)

[22] B. R. Seo, "The structural relationship among satisfaction in major, social support, career decision-making selfefficacy and career preparation behavior of college students majoring in secretarial studies," The Graduate School of Soongsil University, Seoul Korea, (2016)

[23] D. H. Kwon, "The effects of faculty-student interaction and peer relations upon academic self-efficacy of university students," The Graduate School of Sungkyunkwan University, Seoul Korea, (2017)

[24] M. J. Park, "The effect of academic self-efficacy and problem-solving ability of college students on adaptation to college life," The Graduate School of Kookmin University, Seoul Korea, (2017)

[25] S. C. Kim, "The effect of guard majoring students' loyalty on the department of future direction and job choice," The Graduate School of Yong-in University, Gyeonggi-do Korea, (2012)

[26] D. H. Im, "The impact of educational service quality on student loyalty in lifelong learning university mediating effect of college life adaptation," The Graduate School of Chung-Ang University. Seoul Korea, (2016)

[27] J. L. Holand, "Making vocational choices: A theory of vocational personalities and work environments (3rd ed.)," Psychological Assessment Resources, (1997)

[28] H. R. Lee and S. G, Park, "The mediating effect of major satisfaction on the relationship between career barrier and career decision level among college students,” Journal of Foodservice Management Society, vol.13, no.1, pp.79-105, (2010)

[29] K. T. Lee, "The effects of nonverbal communication of professor on students' academic achievement," Journal of Marketing Studies, vol.18, no.4, pp.125-140, (2010) 